\title{
A lead isotope study of anArchaean gold prospect in the Attu region, Nagssugtoqidian orogen, West Greenland
}

\author{
Henrik Stendal, Robert Frei and Bo Møller Stensgaard
}

This paper presents a lead isotope investigation of a gold prospect south of the village Attu in the northern part of the N agssugtogidian orogen in central West G reenland. The Attu gold prospect is a replacement gold occurrence, related to a shear/mylonite zone along a contact between orthogneiss and amphibolitewithin the $\mathrm{N}$ agssugtogidian orogenic belt. Themineral occurrence is small, less than $0.5 \mathrm{~m}$ wide, and can be followed along strike for several hundred metres. The mineral assemblage is pyrite, chalcopyrite, magnetite and gold. The host rocks to the gold prospect are granulite facies 'brown gneisses' and amphibolites. Pb-isotopic data on magnetite from the host rocks yield an isochron in a ${ }^{207} \mathrm{~Pb} /{ }^{204} \mathrm{~Pb}$ vs. ${ }^{206} \mathrm{~Pb} /{ }^{204} \mathrm{~Pb}$ diagram, giving a date of $3162 \pm 43 \mathrm{M} \mathrm{a}$ (M SW D $=0.5$ ). This date is interpreted to represent the age of the rocks in question, and is older than dates obtained from rocks elsewhere within the $\mathrm{N}$ agssugtogidian orogen. $\mathrm{Pb}$-isotopic data on cataclastic magnetite from the shear zone lie close to this isochron, indicating a similar origin. The Pb-isotopic compositions of the ore minerals are similar to those previously obtained from the close-by $\sim 2650 \mathrm{M}$ a Rifkol granite, and suggest a genetic link between the emplacement of this granite and the formation of the ore minerals in the shear/mylonite zone. Consequently, the age of the gold mineralisation is interpreted to be late Archaean.

Keywords: Archaean, gold, magnetite, Pb isotopes, geochronology, W est Greenland

\footnotetext{
H.S. \& B.M .S., Geological Survey of D enmark and G reenland, Ø ster Voldgade 10, D K-1350 Copenhagen K, D enmark. E-mail: hs@@geus.dk

R.F., G eological Institute, U niversity of C openhagen, Ø ster Voldgade 10, D K-1350 C openhagen K, D enmark.
}

D iscovery of the gold prospect described in this study was due to the find of a mineralised sample, which $\mathrm{Karl}$ $M$ arkussen from Attu submitted to the Bureau of $M$ inerals and Petroleum in Greenland. The G eological Survey of Denmark and Greenland (GEUS) visited the locality in 2001 and in 2002 (Stendal et al. 2002, 2004), and the present paper reports $\mathrm{Pb}$-isotopic data for minerals from the prospect and its surroundings.

The Attu gold prospect lies within the N agssugtoqidian orogen of West G reenland (Fig. 1), where geological mapping and exploration has been carried out for decades by the Geological Survey, the Danish Lithosphere Centre, university research groups and exploration companies (e.g.
Kal sbeek et al. 1987; C onnelly et al. 2000; van Gool et al. 2002). In addition to the general investigations, Steenfelt (2001) has summarised geochemical signatures from stream sediments, Rasmussen \& van Gool (2000) have described geophysical aspects, and Steenfelt et al. (2002), Stendal \& Schønwandt (2003) and Stendal et al. (2004) have described mineral occurrences and their economic potential. An overview of the mineral occurrences in the entire region has been presented by Stendal et al. (2004).

$\mathrm{D}$ etailed, mainly zircon U-Pb geochronological data from the $N$ agssugtoqidian orogen have been presented by Kalsbeek \& N utman (1996), Connelly \& M engel (2000) and Connelly et al. (2000), and Pb-Pb, Rb-Sr and Sm- 


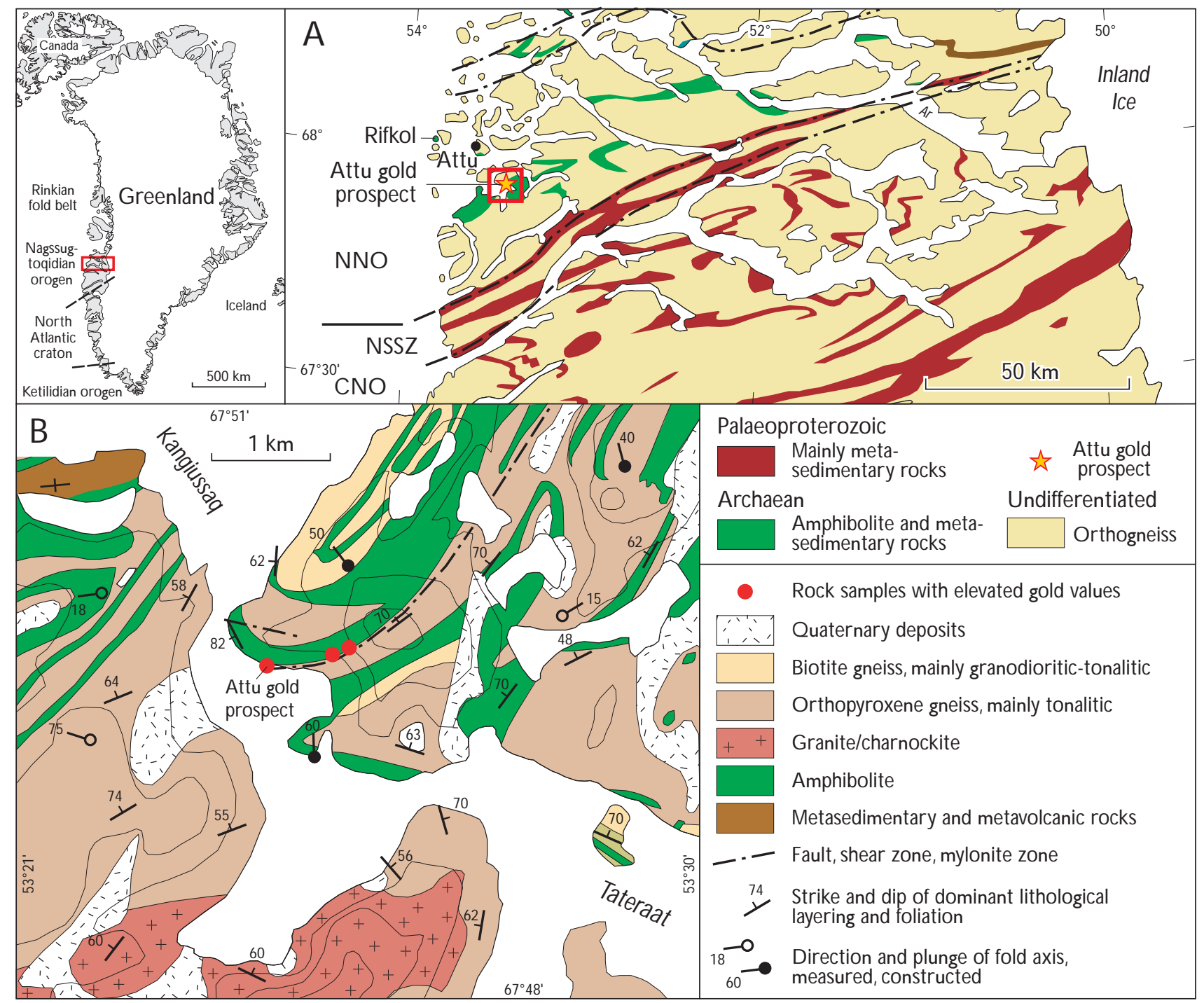

Fig. 1. A: G eological map of the Attu region with index map of Greenland. C N $\mathbf{0}$, central N agssugtogidian orogen; $\mathbf{N} \mathbf{N} \mathbf{0}$, northern N agssugtoqidian orogen; N SSZ, N ordre Strømfjord shear zone. B: G eological map of the Attu gold prospect area (modified from O lesen 1984).

$\mathrm{N} \mathrm{d}$ wholerock isotope data from the region have been reported by K alsbeek et al. (1984, 1987), Taylor \& Kalsbeek (1990) and W hitehouse et al. (1998). In addition, some $\mathrm{Pb}$-isotopic work has been carried out on sulphide separates, mainly pyrite, from mineral occurrences in the Disko Bugt region (Stendal 1998).

\section{Geological setting}

The Palaeoproterozoic N agssugtoqidian orogen of West Greenland (van Gool et al. 2002) is located between the A rchaean N orth Atlantic craton to the south and a lesserknown continental mass to the north that includes the Palaeoproterozoic Rinkian fold belt. M ost of the orogen consists of variably reworked Archaean orthogneisses. Several thin belts of supracrustal and intrusive igneous rocks occur within this gneiss terrain. Granitoid rocks and numerous pegmatites intrude the gneisses. Formations of Palaeoproterozoic age are limited to the Arfersiorfik and Sisimiut igneous suites and minor supracrustal sequences (Connelly et al. 2000).

The Attu area itself is located in the southern part of thenorthern $\mathrm{N}$ agssugtogidian orogen (N N 0 ; Fig. 1). T he metamorphic grade is granulitefacies; metamorphism and deformation of the Archaean granitoid rocks in the N N 0 gradually decrease northwards, from granulite to amphibolite facies, and from high strain to lower strain with moreopen structures. Steeply and shallowly dipping shear and fault zones are common in contact zones between 
Fig. 2. The site of the Attu gold prospect. Gold values are given for rock samples.

Red circles are sample sites with gold values obtained from fine-grained stream sediments (see Fig. 1 for geographical location). The red lineshows the approximate position of the gold-bearing zone in the shear/mylonite zone. T he black line shows the approximate position of a stream.

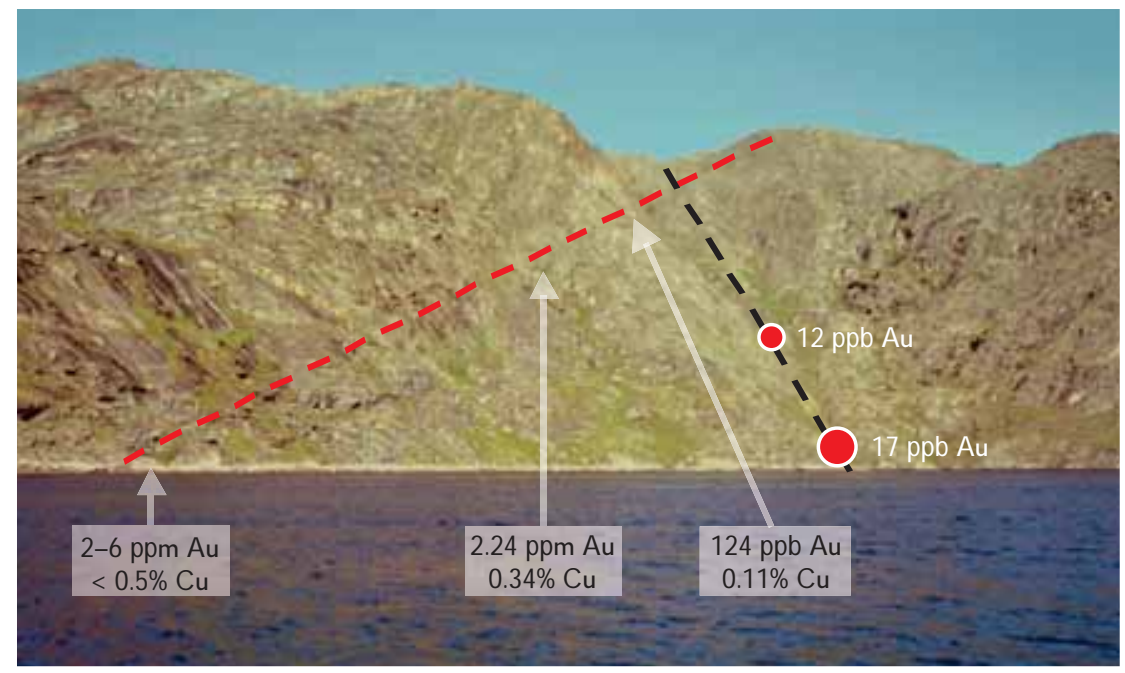

different lithologies. $\mathrm{M}$ ajor fault zones generally strike N NE to NE. The major N ordre Strømfjord shear zone (van Gool 2002) is located c. $20 \mathrm{~km}$ south of the study area. The shear zone is traceable from the coast to the Inland Iceand forms the southern boundary of the $\mathrm{N} N \mathrm{~N}$. The gneisses of the N N $\mathrm{O}$ are late Archaean, with ages between 2870 and $2700 \mathrm{M} \mathrm{a}$ (K alsbeek \& N utman 1996; Connelly\& M engel 2000; $\mathrm{H}$ ollis et al. 2006, this volume; Thrane\& Connelly 2006, this volume). D iscordant sheets of granitoid rocks of Archaean age occur in the centre of the N N $\mathrm{O}$ and large charnockite/granite bodies including the Rifkol granite are situated $20 \mathrm{~km}$ to the northwest and just south of the study area (Fig. 1; H ansen 1979; K alsbeek et al. 1984). O nly a few younger Palaeoproterozoic ages have been obtained from the N N 0 : Thrane\&
Connelly (2006, this volume) have obtained an approximate depositional age of the $\mathrm{N}$ aternaq supracrustal belt some $80 \mathrm{~km}$ north-east of Attu of c. 1950-1900 M a, and an undeformed pegmatite between Attu and Aasiaat has yielded an age of C. $1790 \mathrm{M} \mathrm{a} \mathrm{(C} \mathrm{onnelly} \mathrm{\&} \mathrm{M}$ engel 2000).

\section{The Attu gold prospect}

The Attu gold prospect is located south of the village Attu within a 100-330 m wide, complex tract hosting several parallel shear/mylonite zones and faults that strike N NE to NE and dip 60-70 W (Figs 1, 2). Thefault zone can be followed along strike in a north-easterly direction for several kilometres. The host rocks are layered, brown
Fig. 3. Layered brown gneiss with black bands of amphibolite. The hammer shaft is $50 \mathrm{~cm}$ long.

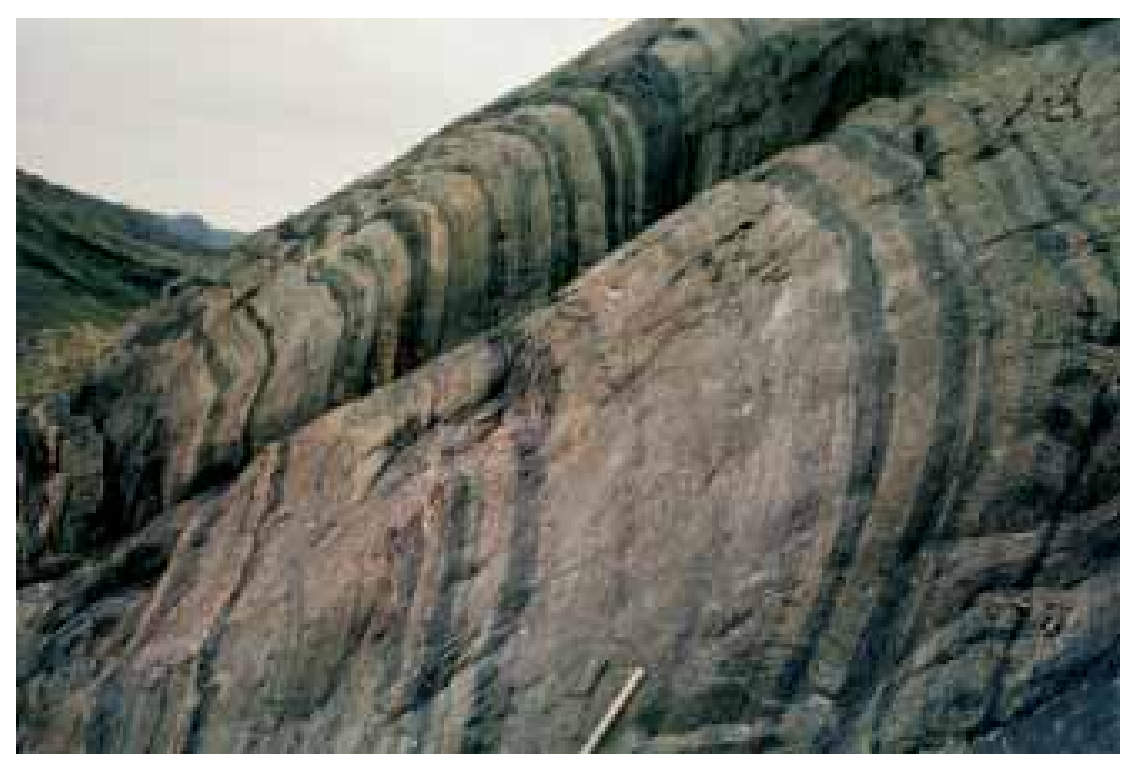




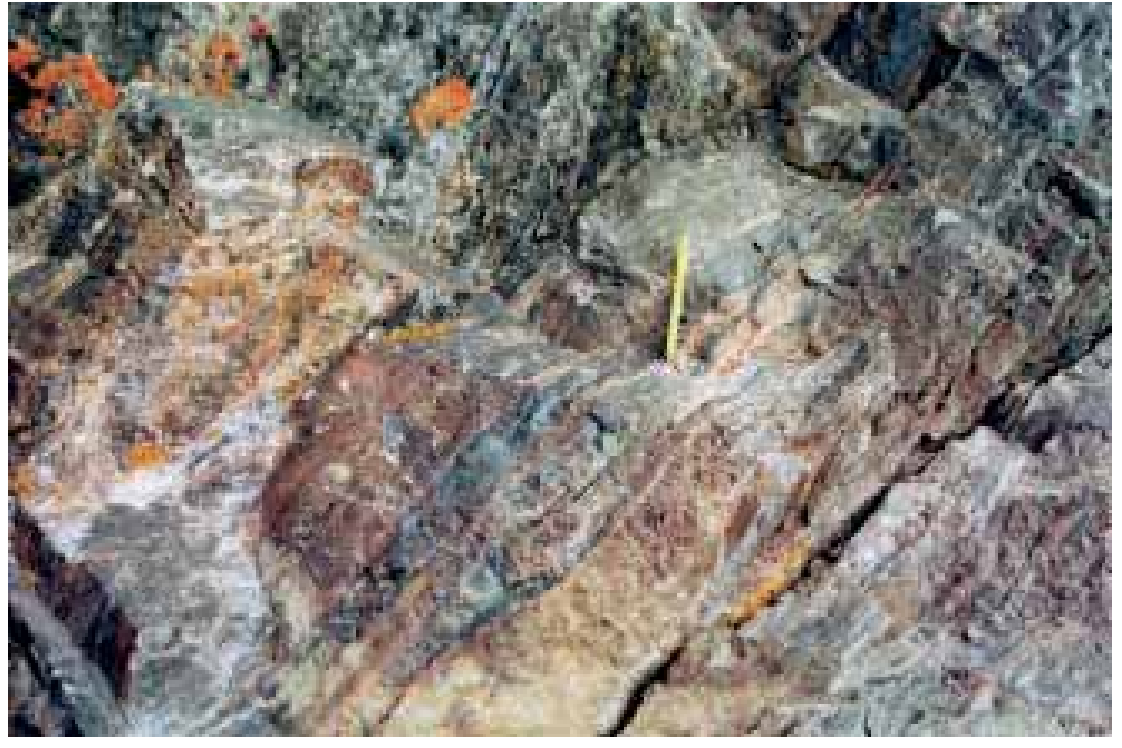

Fig. 4. The gold bearing mylonite zone. Kfeldspar occurs on the right side of the yellow magnet pen $(10 \mathrm{~cm}$ long). The zone also contains pyrite, chal copyrite and magnetite. weathering gneiss and amphibolite (Fig. 3). At the western border of the tract a gold-bearing shear/mylonitezone follows the contact between brown gneisses and amphibolites. The gold-bearing shear/mylonite zone (Fig. 4) is invaded by pegmatite sheets as well as centimetre-wide veins consisting of red alkali-feldspar and quartz with occasional pyrite and magnetite. The estimated relative volume of pegmatite in the tract varies from 1 to $10 \%$ (Stendal et al. 2002, 2004).

Themost promising gold showings are found in a coastal profile along the shear/mylonite zone, which can be followed along strike for several hundreds of metres (Figs $1,2)$. The studied site is a cliff exposure consisting of mylonite (Fig. 4) and a rusty weathered band $(10-20 \mathrm{~cm}$ in width) mineralised with pyrite, magnetite and some chalcopyrite (Fig. 5). Pyrite and chalcopyrite replace magnetite. The magnetite is predominantly cataclastic in nature, but recrystallised orealso occurs. The gold is found within pyrite and chalcopyrite. The gangue mineralogy comprises quartz, K-feldspar, muscovite, biotite and carbonates (calcite, dolomite and/or ankerite).

The mylonite zone is silicified at the contact with the mineralised zone, and sulphide rich parts are weathered. Secondarygoethiteand malachitearecommon (Fig. 5). The ore is structurally controlled by and confined to favourable sites (sulphide-bearing zones) within the mylonite/ shear/fault zone.

TheAttu gold prospect has returned reproducable gold

Table 1. Pb-isoto pic ratios of magnetite, pyrite and K-feldspar from the Attu gold prospect and its host rocks

\begin{tabular}{|c|c|c|c|c|c|c|c|c|c|}
\hline Sample number & Mineral & $206 \mathrm{~Pb} / 204 \mathrm{~Pb}$ & $\pm 2 \sigma^{*}$ & $207 \mathrm{~Pb} / 204 \mathrm{~Pb}$ & $\pm 2 \sigma$ & $208 \mathrm{~Pb} / 204 \mathrm{~Pb}$ & $\pm 2 \sigma$ & $r 1^{* *}$ & $r 2^{\dagger}$ \\
\hline \multicolumn{10}{|c|}{ Amphibolite and orthogneiss (host rocks) } \\
\hline 446601 & magnetite & 14.631 & 0.007 & 14.642 & 0.009 & 44.688 & 0.033 & 0.961 & 0.939 \\
\hline 446602 & magnetite & 15.051 & 0.014 & 14.752 & 0.015 & 36.702 & 0.040 & 0.969 & 0.942 \\
\hline 446610 & magnetite & 17.540 & 0.051 & 15.361 & 0.046 & 37.613 & 0.112 & 0.977 & 0.988 \\
\hline 446614 & magnetite & 17.002 & 0.025 & 15.225 & 0.024 & 38.086 & 0.061 & 0.976 & 0.967 \\
\hline \multicolumn{10}{|c|}{ Shear zone and mineralised rock } \\
\hline 446616 & magnetite & 15.423 & 0.023 & 14.844 & 0.023 & 41.598 & 0.068 & 0.979 & 0.957 \\
\hline 2000368 & magnetite & 15.286 & 0.009 & 14.832 & 0.010 & 41.201 & 0.034 & 0.962 & 0.936 \\
\hline 481093 & magnetite & 14.247 & 0.042 & 14.625 & 0.044 & 41.821 & 0.130 & 0.982 & 0.960 \\
\hline 446615 & pyrite & 14.241 & 0.009 & 14.587 & 0.010 & 42.001 & 0.035 & 0.963 & 0.934 \\
\hline 481078 & pyrite & 14.447 & 0.011 & 14.633 & 0.012 & 40.805 & 0.039 & 0.967 & 0.925 \\
\hline 446616 & K-feldspar & 15.123 & 0.008 & 14.893 & 0.010 & 36.451 & 0.029 & 0.958 & 0.932 \\
\hline
\end{tabular}

* Errors are two standard deviations absolute (Ludwig 1990).

** $r 1={ }^{206} \mathrm{~Pb} / 204 \mathrm{~Pb}$ versus ${ }^{207} \mathrm{~Pb} / 204 \mathrm{~Pb}$ error correlation (Ludwig 1990).

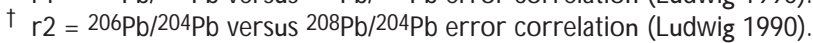


Fig. 5. The gold bearing zone (10 cm wide) within the mylonite zone, with malachite and rusty weathered sulphides.

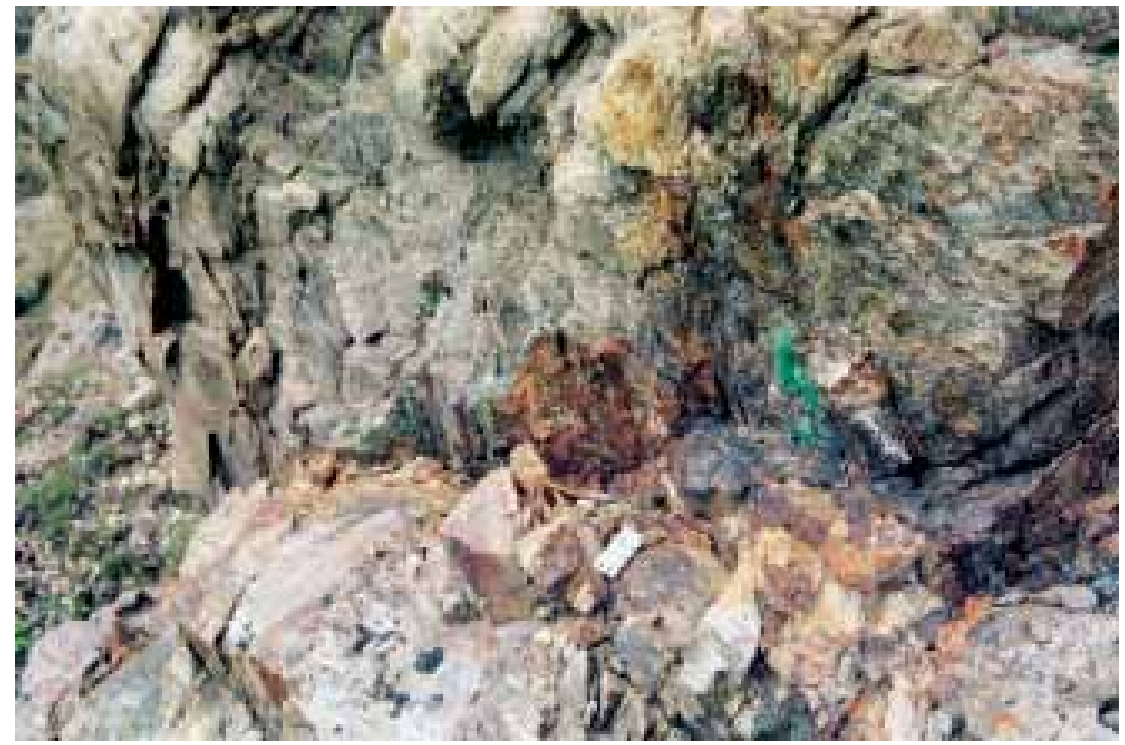

concentrations in the range $2.3-5.8 \mathrm{ppm}$. 0 ther localities in the same fault structure yielded $2.24 \mathrm{ppm}$ and $124 \mathrm{ppb}$ $\mathrm{Au}$ (Fig. 2). The gold concentrations are positively correlated with concentrations of copper, and gold-bearing samples often contain magnetite. Two stream sediment samples yielded anomalous gold concentrations of $12 \mathrm{ppb}$ and $17 \mathrm{ppb} A u$, respectively (Fig. 2).

The host gneisses are brownish in colour and comprise orthopyroxene, amphibole, biotite and feldspar, but little quartz. $M$ agnetite is in equilibrium with the rock forming minerals and has the same granular texture. In the amphibolites magnetite forms up to millimetrethick layers, and also occurs in disseminated form. Within the mylonite zone, magnetite occurs as a primary phase in the host gneiss as cataclastic grains with cracks filled with pyrite and chalcopyrite, and as a residual phase resulting from sulphide replacement. Ten samples were analysed for $\mathrm{Pb}$-isotopic compositions.
Fig. 6. ${ }^{206} \mathrm{~Pb} /{ }^{204} \mathrm{~Pb}-{ }^{207} \mathrm{~Pb} /{ }^{204} \mathrm{~Pb}$ diagram for minerals from the Attu area listed in Table 1. 0 pen squares, mineral separates from the gold-bearing mylonite zone.

Red squares, host rock data.

Black diamonds, whole-rock samples from the Rifkol granite for comparison (data from Kalsbeek et al. 1984). M t, magnetite; Py, pyrite; Kfsp, K -feldspar.

Blue curve, the $\mathrm{Pb}$-isotopic growth curve from Stacey \& Kramers (1975).






\section{Analytical methods}

The $\mathrm{Pb}$-isotopic study was carried out on magnetite from host gneisses and amphibolites, and on K-feldspar, magnetite and pyritefrom the shear zone-hosted mineralised zone (Table 1). The isotope analyses were carried out at the D anish Centre for I sotope G eology, G eological Institute, University of C openhagen. N ear-pure mineral fractions were separated from dry split al iquots of crushed and sieved (100-200 $\mu \mathrm{m})$ rock powders using a hand magnet, a Frantz isodynamic separator and heavy liquid techniques. 0 re minerals were dissolved in concentrated aqua regia. Total procedural blanks for $\mathrm{Pb}$ amounted to $<120 \mathrm{pg}$ which is considered insignificant for the measured $\mathrm{Pb}$-isotopic results, relative to the amount of sample Pb estimated from the mass spectrometer signal intensities. Isotope analyses were carried out on a VG Sector 54-IT instrument in static collection mode. Fractionation for $\mathrm{Pb}$ was controlled by repetitive analysis of the N BS 981 standard (values of Todt et al. 1993) and amounted to $0.103 \pm$ $0.007 \%$ / amu $(2 \sigma ; n=11)$. All results arequoted with $2 \sigma$ precisions.

\section{Results}

The Pb-isotopic compositions of mineral separates from thegold-bearing mylonitezoneand itshost rocks arelisted in Table 1. In the ${ }^{207} \mathrm{~Pb} /{ }^{204} \mathrm{~Pb}$ vs. ${ }^{206} \mathrm{~Pb} /{ }^{204} \mathrm{~Pb}$ diagram shown in Fig. 6, thePb-isotopic compositions of magnetitefrom the four host rock samples of brown gneiss and amphibolite (red squares) define a straight line with a slope corresponding to $3162 \pm 43 \mathrm{Ma}$ (M SWD $=0.50$ ). This line has intercepts with the Stacey \& K ramers (1975) Pb-isotopic growth curve at 3143 and $60 \mathrm{Ma}$. Based on the good fit of the data points on the isochron, and the agreement of theisochron age with theintercepts of the growth curve, we interpret the $3162 \mathrm{M}$ a date as the age of the rocks in question. However, farther south, in the central part of the N agssugtogidian orogen, Palaeoproterozoic granulite facies metamorphism has led to U loss in Archaean rocks, resulting in $\mathrm{Pb}$-isotopic compositions plotting above and to the left of an $2800 \mathrm{M}$ a reference isochron (W hitehouse et. al. 1998). If this process had also taken place in the area of the present study, the $3162 \mathrm{M}$ a date might give a false impression of the age of the rocks. H owever, the good fit of the data points on the isochron and the agreement of theintercepts with theStacey \& Kramers (1975) growth curve with the isochron age would then be accidental, a coincidence which we regard as very unlikely.

Six mineral separates from the gold-bearing mylonite zone (Fig. 6, open squares) lie close to or slightly above the isochron obtained for magnetite from the host rocks. The most primitive ${ }^{206} \mathrm{~Pb} /{ }^{204} \mathrm{~Pb}$ and ${ }^{207} \mathrm{~Pb} /{ }^{204} \mathrm{~Pb}$ ratios have been measured in pyriteand magnetite from theore-bearing zone, whereas the two primary magnetites with cataclastic texture from within the shear zone plot very close to the host rock magnetite isochron. This suggests that their crystallisation took place at about the same time as the magnetites from outside the shear zone. Wholerock $\mathrm{Pb}$-isotopic ratios from the $\mathrm{R}$ ifkol granite (K alsbeek et al. 1984) are also plotted on Fig. 6 for comparison, and the isotopic values are listed in Table 1. The errorchron defined by these samples has a slope corresponding to an age of $2653 \pm 110 \mathrm{M}$ a, which has been interpreted as emplacement age of the granite (Kalsbeek et al. 1984). This errorchron is oblique and discordant to the isochron obtained for magnetite from the host rocks, but the three least radiogenic data points from ore minerals associated with native gold from within the shear zone are conformable with this younger trend. This suggests that the fluids in the shear zone from which the gold mineralisation was deposited were somehow genetically linked to the intrusion of the Rifkol granite. Alkali feldspar from the shear zone has its own $\mathrm{Pb}$-isotopic signature, which is neither compatible with a 'Rifkol' source nor with a source typical of the immediate host rocks.

The uranogenic vs. thorogenic isotopic pattern (not shown in a figure) is more disperse than the uranogenic pattern and doesnot add to theunderstanding of the uranogenic $\mathrm{Pb}$-isotopic data; as expected, it mostly reflects the differences in $U$ and $T h$ concentrations in the different analysed minerals.

\section{Summary, discussion and conclusions}

TheAttu gold prospect issmall. Thegold mineralised zone does not exceed $0.5 \mathrm{~m}$ in width, and its length is now known to be only a few hundred metres. Gold has also been detected along strike several kilometres away, but the mineralisation does not show a continuous outcrop pattern. H owever, the fact that gold is present indicates that the N E-striking shear/mylonite zone is mineralised and that hydrothermal activity seems to have occurred in most of the prominent lineamentsin the region. Thegoldbearing sulphide deposit is of replacement type, where pyrite and chalcopyritegrew at the expense of e.g. magnetite. It is envisaged that gold was introduced contemporaneously with the replacement processes.

Reworked Archaean orthogneisses dominate all segments of the N agssugtogidian orogen. Published age deter- 
minations range from $2870-2700 \mathrm{M}$ a (e.g. Kalsbeek \& N utman 1996; Connelly \& M engel 2000), but no chronological information has yet been available from the Attu region. The $3162 \pm 43 \mathrm{M}$ a magnetite age obtained from the Attu host rocks suggests that the rocks in this part of the Nagssugtogidian orogen may be significantly older than similar rocks elsewhere in the orogen. H owever, Sm$\mathrm{N}$ d isotope data from Archaean gneisses in the central part of the orogen suggest the involvement of pre $2800 \mathrm{M} \mathrm{a}$ crustal material (possibly $3100 \mathrm{M}$ a or older) in their source (W hitehouse et al. 1998). Large parts of the N agssugtoqidian orogen underwent Palaeoproterozoic granulite facies metamorphism around $1850 \mathrm{M} \mathrm{a}$ (e.g. Willigers et al. 2001), which resulted in severe disturbance of the Pbisotopic evolution of the rocks (W hitehouse et al. 1998). In view of the well-preserved $3162 \mathrm{M}$ a isochron relationships for the Attu gneisses it appears possible that these rocksescaped high-grade $\mathrm{N}$ agssugtogidian metamorphism and that granulitefacies metamorphism here is of Archaean age, in agreement with the conclusions of $M$ azur et al. (2006, this volume) and Thrane \& Connelly (2006, this volume).

ThePb-isotopic data of the gold bearing samples (Fig. 6) suggest a genetic link between the R ifkol granite intrusion and the fluids percolating through the shear zone, implying an Archaean age of the mineralisation. W ithout further analytical work we are unable to elaborate and comment on a possible source of the $\mathrm{Pb}$ that has been incorporated into the K-feldspar in the shear zone.

\section{Acknowledgements}

The authors acknowledge F. Kalsbeek, P.M . H olm and an anonymous reviewer for thorough criticism and constructive suggestions, which greatly improved the manuscript. The authors would also like to thank the participants in the resource assessment programme $M$ ineral resources of the Precambrian shield of central West Greenland $\left(66^{\circ}\right.$ $70^{\circ} 15^{\prime} \mathrm{N}$ ) for valuable discussions concerning mineralising events in the region. Input from other scientists in the region is also gratefully acknowledged. Special thanks go to Karl M arkussen, Attu, who submitted the first gold bearing sample, for showing us the exact sample locality.

\section{References}

Connelly, J.N. \& M engel, F.C. 2000: Evolution of Archean components in thePal eoproterozoic N agssugtogidian orogen, West $G$ reenland. G eological Society of America Bulletin 112, 747-763.

Connelly, J.N ., van G ool, J.A.M . \& M engel, F.C. 2000: Temporal evolution of a deeply eroded orogen: theN agssugtogidian orogen, W est Greenland. Canadian J ournal of Earth Sciences 37, 1121-1142.

$H$ ansen, B.F. 1979: Some charnockitic rocksin the Nagssugtogidian of West Greenland. Rapport Grønlands geologiske Undersøgelse 89, 85-96.

H ollis, J.A., Keiding, M ., Stensgaard, B.M ., van Gool, J.A.M . \& G Grde, A.A. 2006: Evolution of N eoarchaean supracrustal belts at the northern margin of the N orth Atlantic C raton, West $\mathrm{G}$ reenland. In: Garde, A.A. \& Kalsbeek, F. (eds): Precambrian crustal evolution and C retaceous-Palaeogenefaulting in West Greenland. Geological Survey of D enmark and Greenland Bulletin 11, 9-31 (this volume).

Kalsbeek, F. \& N utman, A.P. 1996: Anatomy of the Early Proterozoic $N$ agssugtogidian orogen, West $G$ reenland, explored by reconnaissance SH RIM P U -Pb zircon dating. G eology 24, 515-518.

Kalsbeek, F., Taylor, P.N . \& Henriksen, N. 1984: Age of rocks, structures, and metamorphism in the Nagssugtogidian mobile belt, West Greenland - field and $\mathrm{Pb}$-isotope evidence. Canadian Journal of Earth Sciences 21, 1126-1131.

Kalsbeek, F., Pidgeon, R.T. \& Taylor, P.N . 1987: Nagssugtogidian mobile belt of West Greenland: a cryptic $1850 \mathrm{M}$ a suture between two Archaean continents - chemical and isotopic evidence. Earth and Planetary Science Letters 85, 365-385.

M azur, S., Piazolo, S. \& Alsop, G.I. 2006: Structural analysis of the northern Nagssugtogidian orogen, W est Greenland: an example of complex tectonic patterns in reworked high-grade metamorphic terrains. In: Garde, A.A. \& Kalsbeek, F. (eds): Precambrian crustal evolution and $C$ retaceous-Palaeogenefaulting in West Greenland. G eological Survey of D enmark and Greenland Bulletin 11, 163-178 (this volume).

O lesen, N .Ø . 1984: G eological map of G reenland, 1:100 000, Agto 67 V.1 N ord. Copenhagen: $G$ eological Survey of Greenland.

Rasmussen, T.M . \& van Gool, J.A.M . 2000: Aeromagnetic survey in southern West $G$ reenland: project Aeromag 1999. Geology of G reenland Survey Bulletin 186, 73-77.

Stacey, J.S. \& Kramers, J.D. 1975: Approximation of terrestrial lead isotope evolution by a two-stage model. Earth and Planetary Science Letters 26, 207-221.

Steenfelt, A. 2001: G eochemical atlas of Greenland - West and South $G$ reenland. D anmarksog Grønlands $G$ eologiske Undersøgelse Rapport 2001/46, 39 pp., 1 CD-ROM .

Steenfelt, A., Stendal, H., Nielsen, B.M . \& Rasmussen, T.M . 2004: Gold in central West Greenland - known and prospective occurrences. Geological Survey of D enmark and G reenland Bulletin $\mathbf{4}$, 65-68.

Stendal, H . 1998: Contrasting Pb isotopes of Archaean and Palaeoproterozoic sulphidemineralisation, Disko Bugt, central West Greenland. M ineralium D eposita 33, 255-265.

Stendal, H . \& Schønwandt, H .K. 2003: Precambrian supracrustal rocks 
and mineral occurrences, N ortheast D isko Bugt. Danmarksog Grønlands G eologiske Undersøgelse Rapport 2003/24, 57 pp.

Stendal, H ., Blomsterberg, J., Jensen, S.M ., Lind, M ., M adsen, H .B., N ielsen, B.M., Thorning, L. \& Ø stergaard, C. 2002: The mineral resource potential of theN ordre Strømfjord - Q asigiannguit region, southern central West Greenland. Geology of Greenland Survey Bulletin 191, 39-47.

Stendal, H ., Nielsen, B.M ., Secher, K. \& Steenfelt, A. 2004: M ineral resources of the Precambrian shield of central West $G$ reenland $\left(66^{\circ}\right.$ to $70^{\circ} 15^{\prime}$ ). Part 2. Mineral occurrences. Danmarks og Grønlands G eologiskeU ndersøgelse Rapport 2004/20, 212 pp.

Taylor, P.N . \& Kalsbeek, F. 1990: D ating the metamorphism of Precambrian marbles: examples from Proterozoic mobilebelts in Greenland. Chemical G eology 86, 21-28.

Thrane, K. \& Connelly, J.N. 2006: Zircon geochronology from the Kangaatsiaq- $Q$ asigiannguit region, the northern part of the 1.9$1.8 \mathrm{G}$ a N agssugtogidian orogen, West Greenland. In: Garde, A.A. $\&$ Kalsbeek, F. (eds): Precambrian crustal evolution and C retaceous-
Palaeogene faulting in West G reenland. G eological Survey of D enmark and Greenland Bulletin 11, 87-99 (this volume).

Todt, W., Cliff, R.A., H anser, A.\& H ofmann, A.W. 1993: Re-calibration of N BS lead standards using a ${ }^{202} \mathrm{~Pb}+{ }^{205} \mathrm{~Pb}$ double spike. Terra Abstracts 5, Supplement 1, 396 only.

van Gool, J .A.M ., Connelly, J.N ., M arker, M . \& M engel, F. 2002: The $N$ agssugtogidian orogen of West Greenland: tectonic evolution and regional correlations from aW est Greenland perspective. $C$ anadian Journal of Earth Sciences 39, 665-686.

W hitehouse, M .J., Kalsbeek, F. \& N utman, A.P. 1998: Crustal growth and crustal recycling in the $\mathrm{N}$ agssugtogidian orogen of $\mathrm{W}$ est $\mathrm{G}$ reenland: constraints from radiogenic isotope systematics and $\mathrm{U}-\mathrm{Pb}$ zircon geochronology. Precambrian Research 91, 365-381.

W illigers, B.J.A., Krogstad, E.J. \& Wijbrans, J.R. 2002: Comparison of thermochronometers in a slowly cooled granulite terrain: N ags sugtoqidian orogen, West G reenland. J ournal of Petrology 42, 17291749. 